\title{
In vivo sensitivity reduction of Puccinia triticina races, causal agent of wheat leaf rust, to DMI and QoI fungicides
}

\author{
Gisele da Silva Arduim¹, Erlei Melo Reis ${ }^{1,2}$, Amarilis Labes Barcellos ${ }^{3}$, Camila Turra ${ }^{3}$
}

${ }^{1}$ Faculdade de Agronomia e Medicina Veterinária, Universidade de Passo Fundo, Passo Fundo, RS - Brazil; ${ }^{2} \mathrm{Fellow}$ of CNPq; ${ }^{3} \mathrm{OR}$ Melhoramento de Sementes Ltda, Passo Fundo, RS, Brazil.

Autor para correspondência: Erlei Melo Reis (erleireis@upf.br)

Data de chegada: 01/04/2011. Aceito para publicação em: 13/08/2012.

\begin{abstract}
Arduim, F.S.; Reis, E.M.; Barcellos, A.L.; Turra, C. In vivo sensitivity reduction of Puccinia triticina races, causal agent of wheat leaf rust, to DMI and QoI fungicides. Summa Phytopathologica, v.38, n.4, p.306-311, 2012.

Experiments were carried out to determine in vivo the $\mathrm{IC}_{50}$ and the $\mathrm{IC}_{90}$ for demethylation-inhibitor fungicides (DMIs, triazoles) and quinone outside inhibitors (QoIs, strobilurins) to the five most frequent races of Puccinia triticina in 2007 growing season in Southern Brazil. The tests were done in a greenhouse with wheat seedlings. DMI fungicides were tested at the concentrations, in $\mathrm{mg} / \mathrm{L}, 0.0 ; 0.02 ; 0.2$; $2.0 ; 20.0 ; 100.0$ and 200.0 , and QoIs at the concentrations 0.0 ; $0.0001 ; 0.001 ; 0.01 ; 0.1 ; 1$ and $10.0 \mathrm{mg}$ of active ingredient/L water. Fungicides were preventively applied at 24 hours before the inoculation of seedlings with the fungal spores. The effect of treatments was

assessed based on the number of uredia $/ \mathrm{cm}^{2}$. The lowest $\mathrm{IC}_{50}$ (inhibitory concentration) for DMI fungicides determined for MCG-MN, sensitive race, ranged from 0.33 to $0.91 \mathrm{mg} / \mathrm{L}$, while the highest values for MDP-MR, MDT-MR, MDK-MR, MFH-HT races, varied from 9.63 to $85.64 \mathrm{mg} / \mathrm{L}$ (suspected insensitivity). QoI fungicide presented an $\mathrm{IC}_{50}$ varying from 0.0018 to $0.14 \mathrm{mg} / \mathrm{L}$. The sensitivity reduction factor for DMIs varied from 8.8 to 238.8, and for QoIs from 0.3 to $1.5 \mathrm{mg} / \mathrm{L}$. Sensitivity reduction was confirmed for the races MDPMR, MDT-MR, MDK-MR, MFH-HT to DMIs, as well as their sensitivity to QoI fungicides.
\end{abstract}

Additional keywords: $\mathrm{IC}_{50}$, fungicide resistance, sensitivity reduction factor.

\section{RESUMO}

Arduim, F.S.; Reis, E.M.; Barcellos, A.L.; Turra, C. Redução da sensibilidade de raças de Puccinia triticina, agente causal da ferrugem da folha do trigo, aos fungicidas DMI e QoI, in vivo. Summa Phytopathologica, v.38, n.4, p.306-311, 2012.

Experimentos foram conduzidos para determinar, in vivo a $\mathrm{IC}_{50} \mathrm{e}$ $\mathrm{CI}_{90}$ para fungicidas inibidores da demetilação (IDM)(triazois) e inibidores da quinona externa (IQe) (estrobilurinas) a cinco raças de Puccinia triticina mais frequentes na safra 2007, no Sul do Brasil. Os experimentos foram realizados em câmara de crescimento com plântulas de trigo. Os fungicidas IDMs foram testados nas concentrações em $\mathrm{mg} / \mathrm{L}$ de 0,$0 ; 0,02 ; 0,2 ; 2,0 ; 20,0 ; 100,0$ e 200,0 e os IQes nas concentrações de 0,$0 ; 0,0001 ; 0,001 ; 0,01 ; 0,1,1$ e 10,0 $\mathrm{mg}$ de ingrediente activo/L de água. Os fungicidas foram aplicados preventivamente 24 horas antes da inoculação das plântulas com os esporos do fungo. O efeito dos tratamentos foi avaliado pelo número de urdias $/ \mathrm{cm}^{2}$. A menor $\mathrm{IC}_{50}$ (concentração inibitória) para fungicidas DMI determinados para MCG-MN, raça sensível, variaram de 0,33 a 0,91 e os maiores valores de MDP-MR, MDT-MR, MDK-MR, MFHHT corridas, variou de 9,63 a 85,64 mg/L (suspeitas de insensibilidade). $\mathrm{A} \mathrm{CI}_{50}$ dos fungicidas IQes variou de $0,0018-0,14 \mathrm{mg} / \mathrm{L}$. O fator de redução da sensibilidade para os DMIs variou de $8,8-238,8$ e para os IQEs de 0,3-1,5 mg/L. Foi confirmada a redução na sensibilidade de raças MDP-MR, MDT-MR, MDK-MR, MFH-HT para DMIS e sua sensibilidade aos fungicidas IQe.

Palavras-chave adicionais: $\mathrm{IC}_{50}$, fungicida resistência, fator de redução da sensibilidade.

Diseases are among the main factors that have limited wheat production in Brazil. Most of the fungal diseases are favored by weather conditions with predominance of high temperature and frequent rainfall (2). Among the main fungal diseases of wheat, leaf rust, caused by Puccinia triticina Eriks, is considered one of the most important crop diseases causing damage of up to $63 \%(2,5)$.

The main strategies for leaf rust control have been the development and the cultivation of cultivars with genetic resistance and the application of fungicides to above-ground plant parts $(26,27)$. The genetic resistance of wheat to $P$. triticina is not durable due to the high variability of this fungus, resulting in the occurrence of at least one new virulent race in almost each wheat growing season (6). The earliest identification of leaf rust physiologic races in Brazil dates from 1949 and started in the former "Instituto Agronômico do Sul" (IPEAS Pelotas-RS). There are reports of 26 races identified in samples collected from 1949 to 1952 , with the use of an international differential set. In the period from 1952 to 1957, using a group of additional cultivars to the international set, $24 P$. triticina races were determined (2). Until 2007 growing season, 60 races of the fungus were identified in Brazil (Barcellos \& Chaves 2003). In this pathosystem, genetic variability (vertical resistant genes) is well known for the host and the fungus concerning virulence $(2,3,7,8,24)$. 
In 2006/2007 growing season, after 16 years of use of the fungicide tebuconazole (23), 14 years of cyproconazole (24) and seven years of epoxiconazole (25), complaints arose from farmers and technicians about the low efficiency of leaf rust control in commercial wheat fields, to where demethylation inhibitor (DMI) fungicides were applied alone. This fungicide group was most efficient in controlling wheat leaf rust, especially tebuconazole, which as widely used.

A hypothesis for the control failure observed in several wheat fields was that such inefficiency could be attributed to the reduced sensitivity of the fungus to the DMI fungicides used for 16 years and to new $P$. triticina races. To test this hypothesis, the present study was conducted to compare, based on the $\mathrm{IC}_{50}$ and $\mathrm{IC}_{90}$ values, the sensitivity of $P$. triticina races to demethylation inhibitors (DMI) and quinone outside inhibitors (QoI).

\section{MATERIALAND METHODS}

The experiment was conducted at OR - Seed Improvement Ltd. and at the Laboratory of Plant Pathology - Mycology, University of Passo Fundo, Brazil, from July 2007 to July 2008.

Survey of Puccinia triticina races. In this study, 116 samples of P. triticina were collected in wheat fields in Rio Grande do Sul (RS), Parana (PR) and São Paulo (SP) States in 2007 growing season. Races were identified by using the methodology described by McIntosh et al. (19) and grouped according to the North American nomenclature (B) system (18) and the Brazilian nomenclature (B) correspondent, for avirulence $\leftarrow / \rightarrow$ virulence to 19 named $L r$ (Leaf rust) genes: $L r l$, Lr2a, Lr2c, Lr3 (Set 1); Lr9, Lr16, Lr24, Lr26 (Set 2); Lr3ka, Lr11, Lr17, Lr30 (Set 3); Lr10, Lr18, Lr21, Lr23 (Set 4); Lr14a, Lr14b, $\operatorname{Lr} 10+\operatorname{Lr} 26, \operatorname{Lr} 20$ (Set 5); and Lr3bg, Lr19, Lr 27+Lr31 LrTp (6).

The sensitivity of current races (including the dominant ones) was compared to an older race MCG-MN (B34), isolated from Ônix cultivar. This race was first detected in 1989 wheat growing season, which in preliminary tests showed sensitivity to DMI fungicides.

Wheat cultivars: Wheat cultivars Ônix, Abalone, Fundacep 52 and CD 104; genetic domain of OR - Seed Improvement Ltd. - RS FUNDACEP - RS, and COODETEC - PR, respectively, were used. Seedlings were grown in 300-mL pots containing vermiculite and compost at 3:1 proportion; five wheat seedlings were grown in each pot as an experimental unit.

IC $_{50}$ determination: The method to quantify the sensitivity of biotrophic fungi to fungicides described in FRAC (Frac 1991; Frac 1992) protocol was used throughout this study. The tool used to measure the sensitivity of races was the $\mathrm{IC}_{50}$ (inhibitory concentration of fungicide that reduces by $50 \%$ the number of uredia $/ \mathrm{cm}^{2}$ ) and the $\mathrm{IC}_{90}$ determined in in vivo tests.
Five DMI fungicides were tested: (1) epoxiconazole (Opus CE 125); (2) metconazole (Caramba SL 90); (3) tebuconazole (B) (Bayer Folicur CE 200); (4) cyproconazole (Alto 100 SC 100; (5) tebuconazole (M) (Milenia Orius CE 250) (Table 1) at active ingredient concentrations, in $\mathrm{mg} / \mathrm{L}, 0,0.02,0.2,2,20,100$ and 200 and, three QoI (1) azoxystrobin (Priori F 25), (2) pyraclostrobin (Comet CE 25) and (3) trifloxystrobin (Flint WG 50) at concentrations, in $\mathrm{mg} / \mathrm{L}, 0$, $0.0001,0.001,0.01,0.1,1$ and 10 , applied preventively on wheat seedling leaves, according to Hewitt (15), at 24 hours before inoculation.

The inoculum multiplication of each individual race was performed according to the methodology described by McIntosh et al. (19) and Reis (24). For inoculation, uredospores of $P$. triticina races were suspended in mineral oil Soltrol and sprayed with a compressed air device. Subsequently, water was sprayed [Tween 20, two drops/L water (Polyoxy ethylene sorbitane monolaurate - Synth)] prior to runoff. After 24 hours, in a moist chamber, in the absence of light, with $100 \%$ relative humidity at $20^{\circ} \mathrm{C}$, seedlings were transferred to a greenhouse under natural light and partial control of temperature and relative humidity, where they were maintained for approximately 15 days until evaluation.

The effect of treatments was assessed by counting the uredia number $/ \mathrm{cm}^{2}$ on the leaf surface with more uniform uredinium distribution. A hand lens (10 x magnification) with a delimited marked area of $1.0 \mathrm{~cm}^{2}$ was positioned on the leaf blade.

Experimental design was in completely randomized blocks with five replicates. Each fungal race (5) tested with all fungicide (8) at their concentrations (7) constituted one experiment. To increase data reliability, all tests were repeated twice.

Weilbull's model equation four $(\mathrm{y}=\mathrm{d} \exp \{-\exp [\mathrm{b}(\log \mathrm{x}-$ $\mathrm{e}]\})[$ where $(\mathrm{y}=$ concentration of active ingredient $(\mathrm{mg} / \mathrm{L})$ and $\mathrm{x}=$ mycelial growth], described by Knezevic et al. (17), was used to determined $\mathrm{IC}_{50}$ and $\mathrm{IC}_{90}$.

Sensitivity reduction factor (SRF): A useful tool to quantify the shift in the sensitivity of a fungus to a fungicide is the sensitivity reduction factor. $\mathrm{SRF}=\mathrm{IC}_{50}$ of suspected race/ $\mathrm{IC}_{50}$ of the sensitive race (race MCG-MN). When there was no shift in sensitivity, the $\mathrm{SRF}$ value for that race was 1 , and when there was shift $>1$ with different magnitudes (12).

\section{RESULTS}

Identification of races. Of a total of 34 samples of $P$. triticina collected in the state of Rio Grande do Sul, 2.94\% were identified as race MDP-MR (B58), 2.94\% as race MCP, 5.88\% as MCG-MN (B34), $8.82 \%$ as MDT-MR (B55), $35.29 \%$ as MFH-HT and $44.12 \%$

Table 1. $\mathrm{IC}_{50}^{\mathrm{z}}$ and $\mathrm{IC}_{90}$ for cyproconazole for different races of Puccinia triticina (Uredia number/ $/ \mathrm{cm}^{2}$ )

\begin{tabular}{|c|c|c|c|c|c|c|c|c|}
\hline \multirow[b]{2}{*}{ Races } & \multicolumn{4}{|c|}{ First experiment } & \multicolumn{4}{|c|}{ Second experiment } \\
\hline & $\mathrm{IC}_{50}$ & Error & $\mathrm{IC}_{90}$ & Error & $\mathrm{IC}_{50}$ & Error & $\mathrm{IC}_{90}$ & Error \\
\hline MFH-HT & 21.05 & 4.60 & 260.68 & 61.40 & 28.93 & 2.43 & 134.62 & 15.93 \\
\hline MDT-MR & 53.16 & 10.14 & 121.43 & 38.97 & 56.52 & 8.18 & 120.32 & 28.41 \\
\hline MDP-MR & 82.06 & 7.84 & 258.11 & 22.57 & 78.79 & 8.77 & 319.67 & 39.10 \\
\hline
\end{tabular}

( $\left.{ }^{2}\right) \mathrm{IC} \mathrm{mg} / \mathrm{L}$ of active ingredient. 
as MDK-MR (B55 4002S). In the state of Parana, 60 samples were processed, resulting in $1.67 \%$ of race MFP-CT (B56), $3.33 \%$ of TFK-CS (B49), 5\% of TFT-MR (B57), 8.33\% of MDP-MR, $13.33 \%$ of MDT-MR, and $63.33 \%$ of MDK-MR 4002S. In the state of São Paulo, from 22 samples, $4.54 \%$ were identified as race MDT-MR, $18.18 \%$ as MDP-MR and $77.27 \%$ as MDK-MR 4002S.

The races that have emerged more recently were MDT-MR, first detected in 2004, MDP-MR and MFP-CT in 2005 and MDK-MR 4002S, as well as MFH-HT and TFT-MR, in 2007. The dominant race in 2007 growing season was MDK-MR 4002S, followed by MFH-HT, MDT-MR (B55) and MDP-MR (in parenthesis are races named according to Brazilian nomenclature).

Inhibitory concentrations for DMI. (Tables 1, 2, 3, 4 and 5) For the race MCG-MN, considered a standard for sensitivity, $\mathrm{IC}_{50}$ overall mean for all fungicides was $0.69 \mathrm{mg} / \mathrm{L}$ (Table 6), which shows the sensitivity of this race to DMI fungicides. Among the tested races, suspected of having reduction in sensitivity, there were differences in $\mathrm{IC}_{50}$. The lowest $\mathrm{IC}_{50}$ value was obtained for MFT-HT race, $16.84 \mathrm{mg} /$ L. The highest value was found for MDT-MR 55.08, MDK-MR
55.56 and MDP-MR, $70.28 \mathrm{mg} / \mathrm{L}$. Metconazole showed in the overall mean the highest fungitoxicity, $\mathrm{IC}_{50}$ of $26.79 \mathrm{mg} / \mathrm{L}$ (Table 3 ).

Inhibitory concentrations for QoI. (Tables 7, 8 and 9) $\mathrm{IC}_{50}$ values for strobilurin ranged from 0.021 for trifloxystrobin to 0.0053 $\mathrm{mg} / \mathrm{L}$ for pyraclostrobin, and from 0.01 for MDK-MR to $0.0059 \mathrm{mg} /$ L for MFT-HT race (Table 10). Trifloxystrobin was the least toxic while pyraclostrobin, the most toxic fungicide.

Sensitivity reduction factor. Another procedure to show shift in a fungus sensitivity is SRF determination. Regarding DMIs, the lowest SRF was found for race MHF-HT, requiring a 31.0-fold higher concentration, while the highest SRF required a 110.66-fold higher concentration, for race MDP-MR. Regarding fungitoxicity, tebuconazole (B) was the most toxic fungicide, requiring a 80.7fold higher concentration, while the least toxic was cyproconazole which required a 187.8-fold higher concentration (Table 11). Regarding QoIs, the most sensitive race was MHF-HT, 0.45-fold higher, and the least sensitive race was MDP-MR, 1.11-fold higher. Among fungicides, trifloxystrobin showed the lowest fungitoxicity, 1.25 -fold higher (Table 11).

Table 2. $\mathrm{IC}_{50}^{\mathrm{z}}$ and $\mathrm{IC}_{90}$ for epoxiconazole for different races of Puccinia triticina (Uredia number/ $\mathrm{cm}^{2}$ )

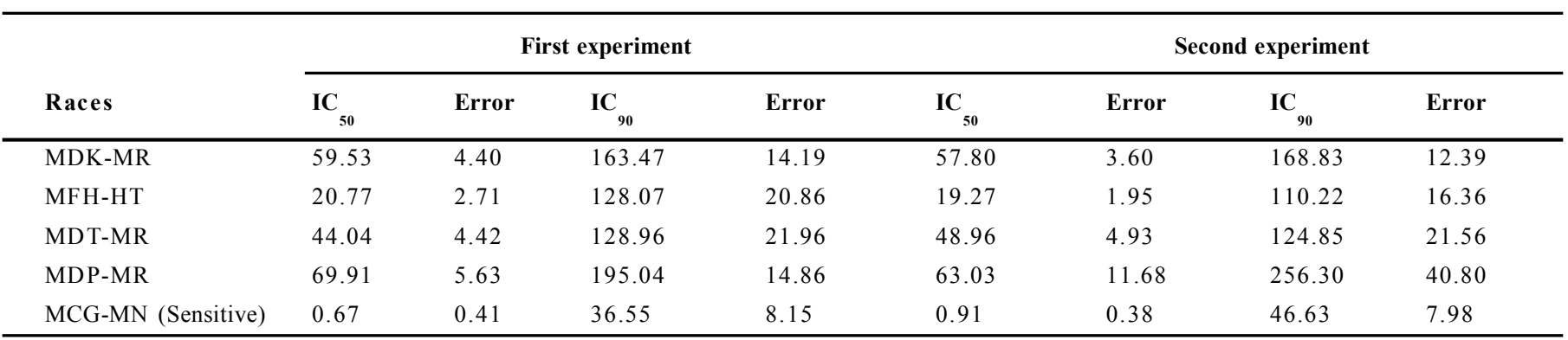

$\left.{ }^{(}\right) \mathrm{IC} \mathrm{mg} / \mathrm{L}$ of active ingredient.

Table 3. $\mathrm{IC}_{50}^{\mathrm{z}}$ and $\mathrm{IC}_{90}$ for metconazole for different races of Puccinia triticina (Uredia number $/ \mathrm{cm}^{2}$ )

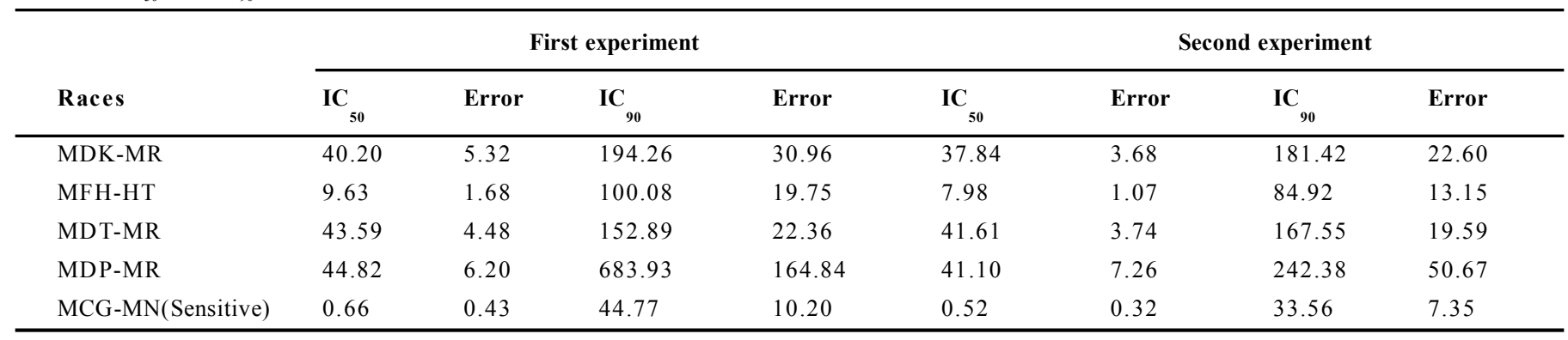

${ }^{(2)} \mathrm{IC} \mathrm{mg} / \mathrm{L}$ of active ingredient.

Table 4. $\mathrm{IC}_{50}^{\mathrm{z}}$ and $\mathrm{IC}_{90}$ for tebuconazole (B) for different races of Puccinia triticina (Uredia number $/ \mathrm{cm}^{2}$ )

\begin{tabular}{|c|c|c|c|c|c|c|c|c|}
\hline \multirow[b]{2}{*}{ Races } & \multicolumn{4}{|c|}{ First experiment } & \multicolumn{4}{|c|}{ Second experiment } \\
\hline & $\mathrm{IC}_{50}$ & Error & IC $_{90}$ & Error & $\mathrm{IC}_{50}$ & Error & $\mathrm{IC}_{90}$ & Error \\
\hline MFH-HT & 10.08 & 1.42 & 103.72 & 18.31 & 13.61 & 1.83 & 135.38 & 21.02 \\
\hline MDT-MR & 64.52 & 5.57 & 202.63 & 17.79 & 65.67 & 5.19 & 217.46 & 17.40 \\
\hline
\end{tabular}

${ }^{(2)} \mathrm{IC} \mathrm{mg} / \mathrm{L}$ of active ingredient. 
Table 5. $\mathrm{IC}_{50}^{\mathrm{z}}$ and $\mathrm{IC}_{90}$ for tebuconazole (M) for different races of Puccinia triticina (Uredia number $/ \mathrm{cm}^{2}$ )

\begin{tabular}{|c|c|c|c|c|c|c|c|c|}
\hline \multirow[b]{2}{*}{ Races } & \multicolumn{4}{|c|}{ First experiment } & \multicolumn{4}{|c|}{ Second experiment } \\
\hline & IC $_{50}$ & Error & $\mathrm{IC}_{90}$ & Error & IC $_{50}$ & Error & $I_{90}$ & Error \\
\hline MDK-MR & 61.30 & 5.38 & 173.76 & 16.19 & 67.59 & 5.39 & 178.97 & 14.20 \\
\hline MFH-HT & 8.92 & 1.39 & 90.82 & 18.09 & 8.83 & 1.15 & 100.18 & 14.18 \\
\hline MDT-MR & 62.85 & 6.37 & 199.61 & 21.01 & 69.91 & 6.20 & 197.84 & 16.61 \\
\hline MDP-MR & 75.99 & 7.52 & 384.86 & 47.44 & 77.58 & 11.09 & 273.69 & 39.02 \\
\hline MCG-MN(Sensitive) & 1.01 & 0.54 & 53.77 & 11.26 & 0.90 & 0.45 & 49.55 & 10.00 \\
\hline
\end{tabular}

$\left.{ }^{(}\right) \mathrm{IC} \mathrm{mg} / \mathrm{L}$ of active ingredient.

Table 6. Sensitivity $\left(\mathrm{CI}_{50}\right)^{\mathrm{z}}$ of Puccinia triticina races to DMI fungicides

\begin{tabular}{|c|c|c|c|c|c|c|}
\hline \multirow[b]{2}{*}{ Fungicide } & \multicolumn{5}{|c|}{ Races } & \multirow[b]{2}{*}{ Mean } \\
\hline & $\begin{array}{c}\text { MGC-MN } \\
\text { (Sensitive pattern) }\end{array}$ & MDK-MR & MFT-HT & MDT-MR & MDP-MR & \\
\hline Cyproconazole & 0.46 & 55.40 & 24.99 & 54.84 & 80.42 & 43.22 \\
\hline Epoxiconazole & 0.79 & 58.66 & 29.77 & 46.50 & 66.47 & 40.44 \\
\hline Metconazole & 0.59 & 39.02 & 8.80 & 42.60 & 42.96 & 26.79 \\
\hline Tebuconazole (B) & 0.70 & 60.29 & 11.85 & 65.09 & 84.78 & 44.54 \\
\hline
\end{tabular}

( $) \mathrm{IC} \mathrm{mg} / \mathrm{L}$ of active ingredient. Means of two experiments.

Table 7. $\mathrm{IC}_{50}{ }^{2}$ and $\mathrm{IC}_{90}$ for azoxystrobin for different races of Puccinia triticina (Uredia number/ $\mathrm{cm}^{2}$ )

\begin{tabular}{|c|c|c|c|c|c|c|c|c|}
\hline \multirow[b]{2}{*}{ Races } & \multicolumn{4}{|c|}{ First experiment } & \multicolumn{4}{|c|}{ Second experiment } \\
\hline & $\mathrm{IC}_{50}$ & Error & $\mathrm{IC}_{90}$ & Error & $\mathrm{IC}_{50}$ & Error & $\mathrm{IC}_{90}$ & Error \\
\hline MFH-HT & 0.0021 & 0.0003 & 0.066 & 0.0109 & 0.0018 & 0.0002 & 0.058 & 0.0090 \\
\hline MDT-MR & 0.0053 & 0.0006 & 0.295 & 0.0418 & 0.0049 & 0.0004 & 0.24 & 0.0327 \\
\hline MDP-MR & 0.0075 & 0.0011 & 1.049 & 0.1694 & 0.0070 & 0.0009 & 0.94 & 0.1416 \\
\hline
\end{tabular}

$\left({ }^{2}\right) \mathrm{IC} \mathrm{mg} / \mathrm{L}$ of active ingredient.

Table 8. $\mathrm{IC}_{50}{ }^{2}$ and $\mathrm{IC}_{90}$ for pyraclostrobin for different races of Puccinia triticina (Uredia number/ $/ \mathrm{cm}^{2}$ )

\begin{tabular}{|c|c|c|c|c|c|c|c|c|}
\hline \multirow[b]{2}{*}{ Races } & \multicolumn{4}{|c|}{ First experiment } & \multicolumn{4}{|c|}{ Second experiment } \\
\hline & IC $_{50}$ & Error & IC $_{90}$ & Error & $\mathrm{IC}_{50}$ & Error & IC $_{90}$ & Error \\
\hline MFH-HT & 0.0034 & 0.0008 & 0.42 & 0.1332 & 0.0025 & 0.0007 & 0.32 & 0.0946 \\
\hline MDT-MR & 0.0081 & 0.0019 & 1.51 & 0.4084 & 0.0074 & 0.0016 & 1.22 & 0.3072 \\
\hline MDP-MR & 0.0053 & 0.0013 & 0.78 & 0.2211 & 0.0051 & 0.0011 & 0.62 & 0.1656 \\
\hline
\end{tabular}

$\left({ }^{z}\right) \mathrm{IC} \mathrm{mg} / \mathrm{L}$ of active ingredient.

Table 9. $\mathrm{IC}_{50}{ }^{2}$ and $\mathrm{IC}_{90}$ for trifloxystrobin for different races of Puccinia triticina (Uredia number $/ \mathrm{cm}^{2}$ )

\begin{tabular}{|c|c|c|c|c|c|c|c|c|}
\hline Races & $\mathrm{IC}_{50}$ & Error & $\mathrm{IC}_{90}$ & Error & $\mathrm{IC}_{50}$ & Error & $\mathrm{IC}_{90}$ & Error \\
\hline MFH-HT & 0.014 & 0.0044 & 1.88 & 0.6323 & 0.013 & 0.0037 & 0.32 & 0.5094 \\
\hline MDT-MR & 0.015 & 0.0050 & 2.73 & 0.9559 & 0.014 & 0.0042 & 1.22 & 0.7600 \\
\hline
\end{tabular}

$\left.{ }^{z}\right) \mathrm{IC} \mathrm{mg} / \mathrm{L}$ of active ingredient. 
Table 10. Sensitivity $\left(\mathrm{IC}_{50}\right)^{\mathrm{z}}$ of Puccinia triticina races to QoI fungicides

\begin{tabular}{|c|c|c|c|c|c|c|}
\hline \multirow{3}{*}{ Fungicide } & \multicolumn{5}{|c|}{ Races } & \multirow{3}{*}{ Mean } \\
\hline & MGC-MN & MDK-MR & MFT-HT & MDT-MR & MDP-MR & \\
\hline & \multicolumn{5}{|l|}{ (Sensitive pattern) } & \\
\hline Azoxystrobin & 0.0065 & 0.0039 & 0.0019 & 0.0051 & 0.0072 & 0.0049 \\
\hline Pyraclostrobin & 0.0050 & 0.0060 & 0.0029 & 0.0077 & 0.0052 & 0.0053 \\
\hline Trifloxystrobin & 0.024 & 0.023 & 0.013 & 0.014 & 0.031 & 0.021 \\
\hline Mean & 0.011 & 0.010 & 0.0059 & 0.0089 & 0.014 & \\
\hline
\end{tabular}

$\left.{ }^{2}\right) \mathrm{IC} \mathrm{mg} / \mathrm{L}$ of active ingredient. Means of two experiments.

Table 11. Sensitivity reduction factor $(\mathrm{SRF})^{\mathrm{z}}$ for Puccinia triticina races to DMI and QoI fungicides

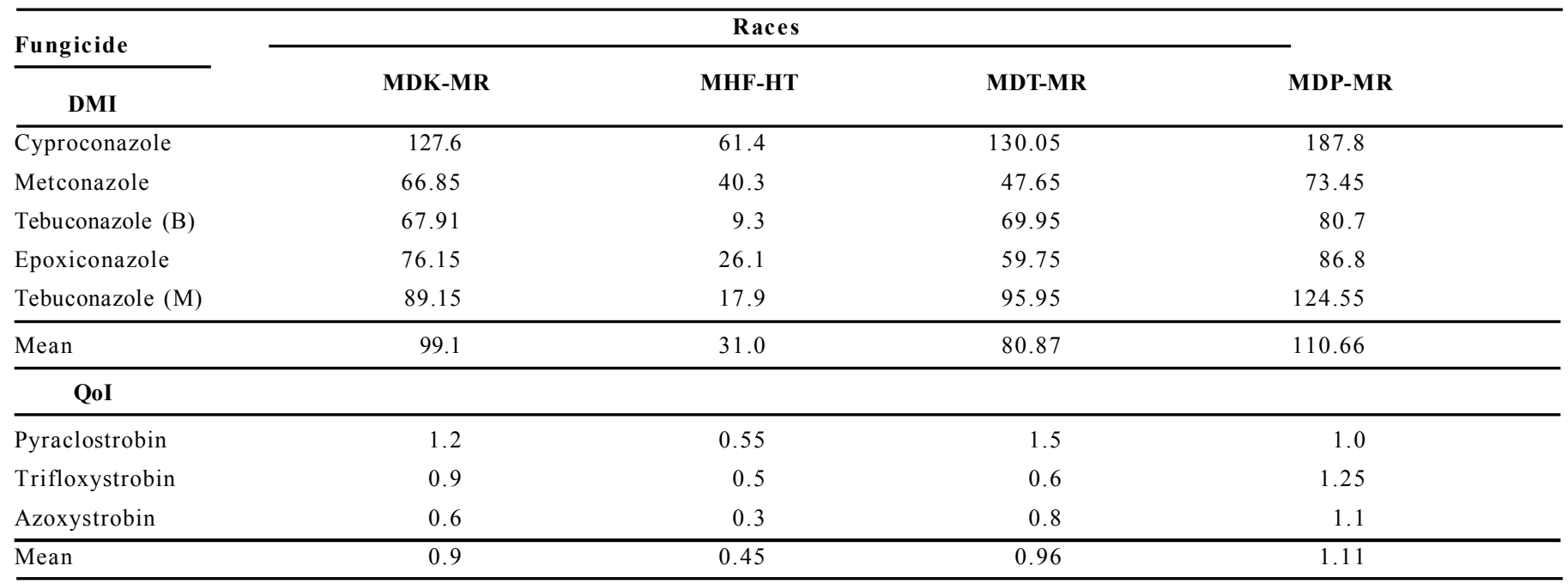

$\left.{ }^{2}\right) \mathrm{IC}_{50}$ for sensitive race MCG-MN taken from Tables 1 and 2 and $=1.0$.

\section{DISCUSSION}

\section{Survey of Puccinia triticina races}

No data on the sensitivity of $P$. triticina races to fungicides was found in the available literature to compare with our findings. The frequent fungus variability has resulted in the occurrence of one new race per growing season $(5,8)$. Race MCG-MN (B34) was identified for the first time in 2000 growing season, before the control failure.

When the $\mathrm{IC}_{50}$ values for the sensitive race were compared with those for other races, the shift in the sensitivity of $P$. triticina races to DMI fungicides was clear, confirming the hypothesis that the observed control failure in wheat crops in 2006 and 2007 seasons could be attributed to the reduced sensitivity of those races to DMI fungicides used for 16 years and in a large acreage.

Inhibitory concentration. Among races, the most sensitive one was MFT-HT and there was cross-sensitivity reduction for DMI fungicides. The least fungitoxic QoI was trifloxistrobin, while the most potent ones were azoxystrobin and pyraclostrobin.

Sensitivity reduction factor. SRF for $P$. triticina races was calculated by considering race MCG-MN values the standard sensitivity $(\mathrm{SRF}=1.0)$.

DMI fungicides: The use of SRF allows data comparison to analyze the occurrence and the magnitude of the reduction in sensitivity to a fungus. SRF shows how many times the $\mathrm{IC}_{50}$ value increases for a sensitive race (baseline) compared to the $\mathrm{IC}_{50}$ of the suspected race. Therefore, the determined $\mathrm{IC}_{50}$ values reinforce the statement that
DMI fungicides should not be used alone for the economic control of wheat leaf rust.

The comparison between the $\mathrm{IC}_{50}$ values of the two fungicide groups leads us to infer that all tested races are still sensitive to QoIs (Table 3) and that the control efficacy obtained in commercial fields is due to the use of QoIs mixed with DMIs.

The DMI fungicide that was most used alone was tebuconazole. The shift in sensitivity of fungi to DMI fungicides is a quantitative phenomenon $(9,12,16)$; hence dose-dependent. Our data showed the occurrence of cross-reduction sensitivity to all DMIs used by growers to control wheat leaf rust.

Up to 2005 wheat growing season, the virulence variability of $P$. triticina was known and well documented, with numerous published studies (3). Moreover, the reduction in sensitivity to fungicides can be considered a new fact here reported by the first time. We have not found any references in the literature about reduction in P. triticina sensitivity to DMI fungicides. However, sensitivity reduction has been reported for Drechslera teres (25), Blumeria graminis f. sp. hordei (14), Blumeria graminis f.sp. tritici (14), Pyrenophora teres (26) and Septoria tritici (16) to DMI fungicides, and for Blumeria graminis f.sp. tritici (1) to strobilurins.

According to the present study, under field conditions growers cannot obtain economic control of wheat leaf rust by spraying DMI fungicides alone. The lowest SRF shifted 8.8 times and the highest one, 238.8 times. Even with 8.8 times, control was not satisfactory and became the target of farmers' complaints. 


\section{REFERENCES}

1. Appel, J. Strobilurin resistance, management strategies and recent results with Apple scab. In: Encontro Nacional Sobre Macieira de Clima Temperado, 3., 2000, SC. Anais, Fraiburgo, p.1320, 2000 .

2. Barcellos, A.L. As ferrugens do trigo no Brasil. ln.: Trigo no Brasil, Fundação EPAGRI, Campinas, 620p. 1982.

3. Barcellos, A.L. Perigo mutante. Cultivar - Grandes Culturas, Pelotas-Rs, ano VllI, n.88, p. 20-23, 2006.

4. Barcellos, A. L.; Chaves, M. S. Epidemias -de ferrugem da folha em cultivares brasileiras de trigo - alterações na população do patógeno de 1993 a 2002. In: SEMINARIO INTERNACIONAL RESITENCIA A ROY AS EM TRlGO, 3., 2003, La Estanzuela. Resumenes ... La Estanzuela: INIA,2003.p. 13.

5. Barcellos, A. L.; Ignaczac, l.C. Efeito da ferrugem. da folha em diferentes estádios de desenvolvimento do trigo. In: Reunião Anual Conjunta de Pesquisa de Trigo, 10., 1978, Porto Alegre. Solos e Técnicas Culturais, Economia e Sanidade: Anais. Passo Fundo: Centro Nacional de Pesquisa de Trigo, 1978. P.212-219.

6. Barcellos, A.L.; Moraes-Femandes, M.I. B.; Roelfs, A.P. Ferrugem da folha do trigo (Puccinia recondita): durabilidade da resistência. Summa Phytopathologica, Botucatu, v. 23, p.101-117. 1997.

7. Carrnona, M.; Reis, E.M.; Cortese, P. Royas deI trigo: sintomas, epiderniología y estrategias de controI. Buenos Aires, 2000; $21 \mathrm{p}$.

8. Chaves, M.S.; Barcellos, A.L. Especialização fisiológica de Puccinia triticina no Brasil em 2002. Fitopatologia Brasileira, Brasília, v. 31, p.057-062, 2006.

9. Forcelini, C.A.; Goellner, c.r., Mio, L.L.M. Resistência de fungos a fungicidas. Revisão Anual de Patologia de Plantas, Passo Fundo, RS, v. 9, n. 1, p. 154-180,2001.

10. Frac. FRAC methods for monitoring fungicides resistance. EPPO Bulletin, Hoboke v. 21, p. 291-354, 1991.

11. Frac. FRAC methods for monitoring the sensitivity. Of fungal pathogens to phenylarnide fungicides. EPPO Bulletin, Hoboke v. 22, p.297-322,1992.

12. Ghini, R.; Kimati, H. Resistência de fungos a fungicidas, Jaguariúna: Embrapa Meio Ambiente, 2000. 78 p.

13.Godet, F.; Limpert, E. Recent evolution of multiple resistance of
Blumeria (Erysiphe) graminis f. sp. tritici to selected DMI and morpholine fungicides in France. Pesticide Science, v. 54, p. $244-$ 252,1998

14. Heaney, S.P.; Humphreys, G,J.; Hutt, R.; Montiel, P.; Jegerings, P.M.F.E. Sensitivity of barley powdery mildew to systemic fungicides in the U'K. In: British Crop Protection Conference - Pests and Diseases, Brighton, U.K. Proceedings ... Croydon, v. 2, p. 459:464, 1984.

15. Hewitt, H.G. Fungicides in crop protection, CAB International Chapter 4. Fungicide Performance, London, p. 87- 153, 1998.

16. Joseph-Horne, T.; Hollomon, D.; Manning, N.; Kelly, S.L. Investigation of the sterol composition and azole resistance of field isolates of Septoria tritici. Applied and Environmental Microbiology, Washiington DC, v. 62, p.184-190, 1996.

17. Knezevic, S.Z.; Streibig, J.C.; Ritz, C. Utilizing R software package for dose-response studies: the concept and data analysis. Weed Technology, Washington DC, v. 21, p. 840-848, 2007.

18. Long, D.L.; Kolmer, J.A. A North American system of nomenc1ature for Puccinia triticina. Phytopathology, St. Paul, v. 79, p. 525-529, 1989.

19. Mcintosh, R.A.; Wellings, C.R.; Park, R.F. Methodologies in wheat rust diseases. ln: Wheat Rusts an atlas of resistance genes. CSIRO, Australia. p. 20, 1995.

20. Reunião da Comissão Sul-brasileira de Pesquisa de Trigo, 22. Porto Alegre. Ata ... Porto Alegre: IPAGRO, 134 p. 1990.

21. Reunião da Comissão Sul-Brasileira de Pesquisa de Trigo, 24. Cruz Alta. Ata ... 2 Cruz Alta: FUNDACEP-FECOTRIGO, 134 p. 1992

22. Reunião da Comissão Sul-Brasileira de Pesquisa de Trigo, 31. Passo Fundo. Ata ... Passo Fundo: Comissão Sul-Brasileira de Pesquisa de Trigo, 1999. $131 \mathrm{p}$.

23. Reunião da Comissão Sul-Brasileira de Pesquisa de Trigo e Triticale, IV. Ata ... Cascavel. 2010.

24. Reis, E.M. Doenças do Trigo V: ferrugens, São Paulo, 1991, 20 p.

25. Reis, E.M.; Casa, R.T.; Blum, M.M.C.; Carmona,; Barreto, D Sensibilidade de Drechslera teres ao fungicida triadimenol usado em tratamento de sementes de cevada. Fitopatologia Brasileira Brasília, v.22, n. 4, p. 539-542, 1997.

26. Sheridan, E.; Grbavac, N.; M.H. Triadimenol insensitivity in Pyrenophora teres. Transactions of the British Mycological Society, Manchester, v. 85, p. 338-341, 1985. 